\title{
Anti-HGF Monoclonal Antibody TAK-701
}

National Cancer Institute

\section{Source}

National Cancer Institute. Anti-HGF Monoclonal Antibody TAK-701. NCI Thesaurus. Code C81939.

A humanized monoclonal antibody directed ag ainst human hepatocyte growth factor (HGF) with potential antineoplastic activity. Anti-HGF monoclonal antibody TAK-701 binds to the soluble lig and HGF, preventing HGF binding to and activation of the HGF receptor c-Met and so the activation of the c-Met signaling pathway; this may result in the induction of cell death in c-Met-expressing tumor cells. c-Met, a receptor tyrosine kinase overexpressed or mutated in a variety of tumor cell types, plays a key role in cancer cell growth, survival, angiogenesis, invasion, and metastasis. 